\title{
Assessment of Undiscovered Gas Resources of the Eastern Oregon and Washington Province, 2006
}

Using a geology-based assessment

methodology, the U.S. Geological Survey estimated a mean of 2.4 trillion cubic feet (TCF) of undiscovered natural gas in the Eastern Oregon and Washington Province. More than 90 percent, or $2.1 \mathrm{TCF}$, of the estimated undiscovered natural gas is continuous gas estimated to be trapped in Tertiary rocks overlain by the Columbia River Basalt Group.

\section{Introduction}

The U.S. Geological Survey (USGS) recently completed an assessment of the undiscovered gas resources of the Eastern Oregon and Washington Province; the province includes about $60,000 \mathrm{mi}^{2}$ in eastern Oregon and Washington (fig. 1). The assessment of the Eastern Oregon and Washington Province was geology based and used the total petroleum system (TPS) concept. The geologic elements of a total petroleum system include hydrocarbon source rocks (source rock maturation, and hydrocarbon generation and migration), reservoir rocks (quality and distribution), and traps for hydrocarbon accumulation. Using these geologic criteria, the USGS assessment team defined the Cretaceous-Tertiary Composite Total Petroleum System. Three assessment units (AU) were defined within the TPS, and undiscovered gas resources within two of the three assessment units were quantitatively estimated (table 1).

Volcanic rocks in the Columbia River Basalt Group, which range in thickness from 4,000 to $13,000 \mathrm{ft}$, overlie a nonmarine sedimentary rock succession in much of the Eastern Oregon and Washington Province area. Some 5,000 to $10,000 \mathrm{ft}$ of arkosic sandstone, mudstone, lacustrine shale, and coal are known to be present below the basalt in north-central Oregon and central Washington; these rocks include potential source and reservoir rocks.

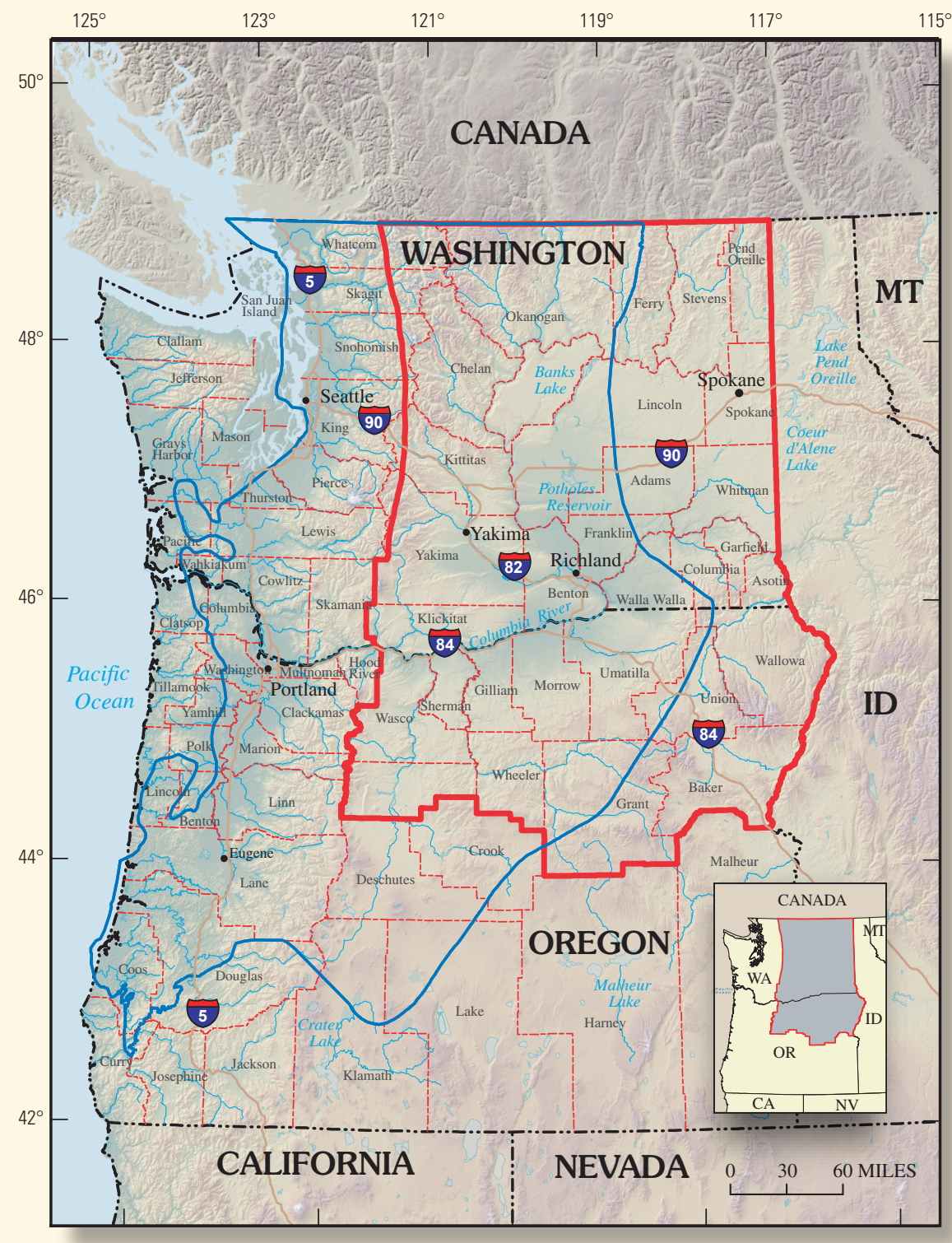

Figure 1. Area of Eastern Oregon and Washington Province located in northcentral and northeastern Oregon and eastern Washington. Province boundary shown in red. Cretaceous-Tertiary Composite Total Petroleum System is shown in blue. 
Table 1. Eastern Oregon and Washington Province assessment results.

[MMBO, million barrels of oil; BCFG, billion cubic feet of gas; MMBNGL, million barrels of natural gas liquids. Results shown are fully risked estimates. For gas fields, all liquids are included under the NGL (natural gas liquids) category. Undiscovered gas resources are the sum of nonassociated and associated gas. F95 represents a 95 percent chance of at least the amount tabulated. Other fractiles are defined similarly. Fractiles are additive under the assumption of perfect positive correlation. Gray shade indicates not applicable]

\begin{tabular}{|c|c|c|c|c|c|c|c|c|c|c|c|c|c|}
\hline \multirow{2}{*}{$\begin{array}{l}\text { Total Petroleum Systems } \\
\text { (TPS) } \\
\text { and Assessment Units (AU) }\end{array}$} & \multirow[t]{2}{*}{$\begin{array}{l}\text { Field } \\
\text { type }\end{array}$} & \multicolumn{8}{|c|}{$\begin{array}{c}\text { Total undiscovered resources } \\
\text { Gas (BCFG) }\end{array}$} & \multicolumn{4}{|c|}{ NGL (MMBNGL) } \\
\hline & & F95 & F50 & F5 & Mean & F95 & F50 & F5 & Mean & F95 & F50 & F5 & Mean \\
\hline \multicolumn{14}{|l|}{$\begin{array}{l}\text { Cretaceous-Tertiary } \\
\text { Composite TPS }\end{array}$} \\
\hline \multirow{2}{*}{$\begin{array}{l}\text { Eastern Oregon and Washington } \\
\text { Conventional Gas AU }\end{array}$} & Oil & 0 & 0 & 0 & 0 & 0 & 0 & 0 & 0 & 0 & 0 & 0 & 0 \\
\hline & Gas & & & & & 0 & 242 & 857 & 305 & 0 & 0.41 & 1.94 & 0.61 \\
\hline Republic Graben Gas AU & & \multicolumn{12}{|c|}{ Not quantitatively assessed } \\
\hline \multirow{2}{*}{$\begin{array}{l}\text { Columbia Basin } \\
\text { Continuous Gas AU }\end{array}$} & & & & & & & & & & & & & \\
\hline & Gas & & & & & 1,179 & 2,013 & 3,436 & 2,122 & 3.12 & 7.85 & 19.79 & 9.20 \\
\hline $\begin{array}{l}\text { Total Undiscovered Oil and } \\
\text { Gas Resources }\end{array}$ & & 0 & 0 & 0 & 0 & 1,179 & 2,255 & 4,293 & 2,427 & 3.12 & 8.26 & 21.73 & 9.81 \\
\hline
\end{tabular}

\section{Resource Summary}

The USGS assessed both undiscovered conventional gas and undiscovered continuous (unconventional) gas in the Eastern Oregon and Washington Province (table 1), resulting in an estimated mean total of 2.4 trillion cubic feet of gas (TCFG) and 9.8 million barrels of natural gas liquids (MMBNGL) (table 1). More than 90 percent (2.1 TCFG) is contained within the hypothetical Columbia Basin Continuous Gas $\mathrm{AU}$, which encompasses an area of more than 4 million acres. Undiscovered resources within this $\mathrm{AU}$ are considered to be within an overpressured, continuous accumulation of gas trapped within Tertiary rocks that are overlain by the Columbia River Basalt Group. An estimated 300 billion cubic feet (BCF) of conventional gas is present in the hypothetical Eastern Oregon and Washington Conventional Gas AU, which contains more than 22.2 million acres. Potential reservoir and source rocks are known or inferred to coexist in this assessment unit, although thick Miocene to Holocene volcanic sequences cover the reservoir and source rock intervals. The Republic Graben Assessment Unit, the third AU defined, was not quantitatively assessed.

\section{For Additional Information}

Supporting geologic studies of total petroleum systems and assessment units, and reports on the methodology used in the Eastern Oregon and Washington Province assessment, are in progress. Assessment results are available at the USGS Central Energy Team website: http://energy.cr.usgs. gov/oilgas/noga/.



Figure 2. Columbia River Basalt Group and the Columbia River, looking north from the Oregon side of the river. The town of Lyle, Washington, is visible on left side of photograph.

\section{Eastern Oregon and Washington Province Assessment Team}

Michael E. Brownfield (mbrownfield@usgs.gov), Marilyn E. Tennyson, Thomas S. Ahlbrandt, Ronald R. Charpentier, Troy A. Cook, Timothy R. Klett, Richard M. Pollastro, and Christopher J. Schenk. 